\title{
COVID-19 and Student Health Care in Ukraine: Do Public Decisions Meet Student Needs?
}

\author{
Mykola Zhurba $^{1,2, *}$, Yuliia Bokhonkova ${ }^{3}$, Dmytro Marchenko ${ }^{4}$, Nataliia Buhaiova ${ }^{3}$, \\ Marharyta Zhurba ${ }^{5}$ \\ ${ }^{1}$ Department of Practical Psychology and Social Work, Volodymyr Dahl East Ukrainian National University, Ukraine \\ ${ }^{2}$ Division of Ukrainian Studies, Jagiellonian University, Poland \\ ${ }^{3}$ Department of Psychology and Sociology, Volodymyr Dahl East Ukrainian National University, Ukraine \\ ${ }^{4}$ Department of Computer Systems and Networks, Volodymyr Dahl East Ukrainian National University, Ukraine \\ ${ }^{5}$ Department of Pharmacology, Clinical Pharmacology and Clinical Pharmacy, Luhansk State Medical University, Ukraine
}

Received February 1, 2021; Revised March 5, 2021; Accepted April 3, 2021

\section{Cite This Paper in the following Citation Styles}

(a): [1] Mykola Zhurba, Yuliia Bokhonkova, Dmytro Marchenko, Nataliia Buhaiova, Marharyta Zhurba, "COVID-19 and Student Health Care in Ukraine: Do Public Decisions Meet Student Needs?," Universal Journal of Public Health, Vol. 9, No. 2, pp. 67 - 74, 2021. DOI: 10.13189/ujph.2021.090205.

(b): Mykola Zhurba, Yuliia Bokhonkova, Dmytro Marchenko, Nataliia Buhaiova, Marharyta Zhurba (2021). COVID-19 and Student Health Care in Ukraine: Do Public Decisions Meet Student Needs?. Universal Journal of Public Health, 9(2), 67 - 74. DOI: 10.13189/ujph.2021.090205.

Copyright $(2021$ by authors, all rights reserved. Authors agree that this article remains permanently open access under the terms of the Creative Commons Attribution License 4.0 International License

\begin{abstract}
There were three main reasons for choosing the topic for this empirical research. The first reason was that the world faced a global threat of the COVID-19 pandemic. The second one was that the new university offering the relative share of e-learning equals $100 \%$ must meet students' needs as educational services buyers. The third reason was that the sudden transition to $100 \%$ of e-learning could affect the mental and physical health of students. The goal of this empirical research was to study whether public decisions on student health care during the COVID-19 pandemic era in Ukraine meet students' needs. The authors have used powerful research methodologies such as literature review, analysis of public decisions on student health care during the COVID-19 pandemic era in Ukraine, experiment planning, questionnaire survey, primary processing and grouping of the results and verification of statistical hypotheses. The study surveyed 142 respondents in seven groups. The authors put forward the key hypothesis: public decisions on student health care during the COVID-19 pandemic era in Ukraine meet student needs in e-learning. This empirical study gives us six new scientific results. Mainly, the comparison of public decisions on student health care during the COVID-19 pandemic era and student needs in e-learning shows that the difference is statistically significant. The alternative hypothesis was accepted: student needs in
\end{abstract}

e-learning are not equal to $100 \%$ if random deviations will not be taken into account. This main scientific result is highly statistically significant $(0,01)$. Additionally, the new scientific result is that the theory of learning should be adjusted taking into account that the share of e-learning equals $100 \%$. Implementation of these and the rest of the new scientific results will improve public decisions on student health care in Ukraine during the COVID-19 pandemic. One of the tasks for the next exploration is to study how the sudden transition to $100 \%$ of e-learning affected mental and physical student health.

Keywords The COVID-19 Pandemic, Health Care, Student Health, Public Decisions, E-Learning, Student Needs

\section{Introduction}

There are three main reasons why the results of this study must be published.

The first reason was that the world faced a global threat of the COVID-19 pandemic. Public decisions in civilized countries have focused on the care of public health. Public decisions on public health have affected various groups of 
the population, including students.

Many universities have temporarily stopped teaching. Many universities have started to use only e-learning methods. The share of e-learning became $100 \%$. A sharp increase in the share of e-learning to $100 \%$ may face resistance from both university teachers and students.

The second one was that the new university offering the relative share of e-learning equals $100 \%$ must meet students' needs as educational services buyers. At the same time, university authorities must respect the students' academic freedoms.

And finally, the sudden transition to $100 \%$ of e-learning can affect the mental and physical health of students.

This study will not cover e-learning methods, quality or tools. It will address the issues of student health care through the organization of the educational process using e-learning. And based on the scientific analysis, practical recommendations will be given to the Ukrainian university authorities.

\section{Literature Review}

Since December 2019, cases of pneumonia, now known as Coronavirus disease (Covid-19), have appeared [1]. The disease has rapidly spread, and the World Health Organization has declared a pandemic [2]. The pandemic of coronavirus disease (Covid-19) seriously impacts the health of all of us [3].

As COVID-19 is rapidly spreading around the world, some countries have launched contact-tracing apps to detect exposure risks. This essay [4] discusses the rise of the Health Code from a platform perspective, developed by Alipay and WeChat, for identifying people potentially exposed to COVID-19. The author states that digital platforms are key players conducting health surveillance and mediating state-citizen relations [4].

The containment of coronavirus disease 2019 (COVID-19) through case investigation and contact tracing is a crucial strategy for governmental public health agencies to control the spread of COVID-19 infection in the United States [5]. This case study [5] of the Anne Arundel County Department of Health (Maryland) illustrates one model of contact-tracing activity developed early in the outbreak. Other local, state, tribal, territorial, and federal health officials and policymakers can use this case study to innovate, iterate, and further, refine contact-tracing efforts to prevent the spread of COVID-19 infection and support community members in isolation or quarantine [5].

In the study [6], the authors attempt to review the prevailing mental health issues during the COVID-19 pandemic. The major mental health issues reported were stress, anxiety, depression, insomnia, denial, anger and fear. Globally, measures have been taken to address mental health issues using the guidelines and intervention strategies. The Government of India [6] used state-specific intervention strategies, telepsychiatry consultations, toll-free number specific for psychological and behavioral issues.

The authors of the paper [7] supposed that exercises can help mitigate mental well-being problems that people are likely to suffer during the COVID-19 pandemic. This study was conducted to establish the relationship between exercise participation and mental well-being during the pandemic. A sample of 1,800 adult residents of Nigeria's Niger Delta was selected using purposive and stratified systematic sampling techniques. It was concluded by the authors [7] that current exercise participation can help in preserving one's mental well-being during the COVID-19 pandemic.

In two papers [3, 8], their authors described issues with health care workers.

The aim of the study [3] was to investigate the psychological impact of Covid-19 on frontline health care workers, including anxiety, depression, stress and perception of the threat of the disease in a designated infectious disease hospital for Covid-19. Among 309 participants, there were $88(28,5 \%)$ people with anxiety and $172(56,0 \%)$ participants with depression [3]. The authors showed that measures to prevent professional exposure are important for frontline health care workers' physical and mental health [3]. It should be given more psychological care to young staffs and nurses.

The editorial paper [8] introduces a special section on nurses' mental health and well-being. It showcases results from a groundbreaking pan-Canadian study of nurses' occupational stress. In this editorial paper [8], the authors review the current stressors faced by nurses and anticipate how nurses' mental health and well-being will be affected by COVID- 19 .

The current COVID-19 pandemic becomes a problem for education [9]. Since March 11, the World Health Organization has declared a pandemic of COVID-19 [2]. Many governments have declared quarantines and other restrictive measures, and the universities have also become objects of restrictions. The universities in many countries have started teaching students using only e-learning methods.

The authors of the study [10] used a Google form questionnaire by asking 104 elite athletes respondents in DKI Jakarta. As many as $76,9 \%$ of athletes stated that the training program was conducted online well. $64,4 \%$ of respondents stated online exercises made the training process easier, and $35,6 \%$ of participants said there were no obstacles. The results of the study [10] found out that online training is suitable for athletes to care athletes' health.

The aim of the study [9] is to explore students' perceptions of online learning and preferred platforms in physical education classes during the COVID-19 pandemic. As many as 60 students become the sample. The results of 
this study showed the students' perceptions consider online learning very important in the current era of COVID-19, and the majority of the platforms that students like the most are Zoom Meetings (30\%). The contribution of this research [9] is that it can provide information to the teachers and lecturers about online learning and platforms that can be used in physical education classes so that later learning outcomes from students can be achieved more optimally.

The works $[9,10]$ showed that e-learning was suitable for students to care students' health. However, they did not show the level of students' need for distance learning. The papers $[9,10]$ did not show whether the students were satisfied by government decisions concerning e-learning during the pandemic era.

In the study [11], University students are referred to as buyers of educational services. The studies [12-14] provide some recommendations to the universities on how to meet the needs of buyers of educational services, i.e., students.

To summarize the literature review, the researchers investigated various measures to care for public health during the pandemic era:

Firstly, case investigation and contact tracing are crucial strategies for governmental public health agencies to control the spread of COVID-19 infection.

Secondly, measures have been taken to address mental health issues using the guidelines and intervention strategies, for example, telepsychiatry consultations, toll-free number specific for psychological and behavioral issues. Current exercise participation can help in preserving one's mental well-being during the COVID-19 pandemic.

Thirdly, the measures to prevent professional exposure are significant for frontline health care workers' physical and mental health. It should be given more psychological care to young staffs and nurses.

And finally, the quarantines and other restrictive measures: the universities in many countries have started teaching students using only e-learning methods. E-learning is suitable for students to care for their health. However, it is not shown whether the students were satisfied by public decisions on e-learning during the COVID-19 pandemic era. And how did the sudden transition to $100 \%$ of e-learning affect the students' mental and physical health?

This empirical study will consider public decisions on student health care and e-learning in Ukraine. First, we will look at public decisions of the Ukrainian government on student health care and e-learning during the COVID-19 pandemic era. Second, we'll study student needs in e-learning in Ukraine. And finally, we are going to compare both of them.

The study result will be useful for public administration representatives and the university authorities to care for student health.

\section{Methods}

\subsection{General Information}

This empirical research was conducted from November 2017 till January 2021 according to the methodology described in [12]. The study analyzes some government documents related to the e-learning of students in Ukraine during the COVID-19 pandemic. Also, the study surveyed 142 respondents. Seven groups of respondents from Ukraine were in the study.

The methods of the research were literature review, analysis of public decisions on student health care during the COVID-19 pandemic era in Ukraine, experiment planning, questionnaire survey, primary processing and grouping of the results. Also, the authors used verification of one pair of statistical hypotheses [12].

The goal of this empirical study was to study whether the public decisions on student health care during the COVID-19 pandemic era in Ukraine meet student needs.

The key hypothesis is that the public decisions on student health care during the COVID-19 pandemic era in Ukraine meet student needs in e-learning.

The object of the study is public decisions on student health care during the COVID-19 pandemic era in Ukraine.

The subject of the study is the relationship between public decisions on student health care and student needs in e-learning.

\subsection{The Analysis of Public Decisions on Student Health Care during the COVID-19 Pandemic Era in Ukraine}

Several public documents of the Ukrainian government related to student health care were examined. The results of the analysis of these documents were used for the comparison of student needs in e-learning.

\subsection{The Experiment Planning}

The ascertaining experiments included three steps:

- the analysis of public decisions on student health care during the COVID-19 pandemic era in Ukraine,

- the analysis of student needs in e-learning in Ukraine,

- the comparison of public decisions on student health care during the COVID-19 pandemic era and student needs in e-learning.

The serial (nested) sampling [15] was used for the ascertaining experiment. The characteristics of the respondents, after the rejection of substandard questionnaires, are given in Appendix 1.

Appendix 1 shows that the study surveyed 142 respondents in seven groups. The matrix of the complete experiment plan is shown in Table 1. 
Table 1. The matrix of the complete experiment plan

\begin{tabular}{|c|c|c|}
\hline No & Specialty & Questionnaire survey \\
\hline 1 & Humanities & + \\
\hline 2 & Technical Sciences & + \\
\hline 3 & Natural Sciences & + \\
\hline
\end{tabular}

Among them were full-time undergraduate and graduate students, students of Humanities, Natural Sciences and Technical Sciences (Table 1, Appendix 1). Each respondent group consisted of 15 to 30 students.

\subsection{Questionnaire Survey}

The questionnaire was borrowed from the study [12]. Concerning the present stage of the study, the main research question for students was about student needs in e-learning.

\subsection{The Grouping of Results and Primary Processing}

The questionnaires for each group of students were statistically processed. The purpose of statistical processing [16-18] was the calculation of the expected value $(\dot{X})$, the standard deviation for the sample $\left(\boldsymbol{\delta}_{\mathbf{x}}\right)$, the standard deviation for the population $\left(\boldsymbol{\delta}_{\mathbf{x}-1}\right)$.

\subsection{Verification of Statistical Hypotheses}

The authors verified the statistical hypotheses according to the statistical textbooks [16-18].

The verification of statistical hypotheses made it possible to transform the subjective opinions of 142 respondents into objective scientific knowledge [16-18].

\subsection{Drawing Conclusion}

After discussions, the authors made conclusions.

\section{Results}

The study covered the relationship between public decisions on student health care during the COVID-19 pandemic era and student needs in e-learning in Ukraine.

\subsection{Public Decisions on Student Health Care during the COVID-19 Pandemic Era in Ukraine}

Since March 11, the World Health Organization has declared a pandemic of COVID-19 [2]. The reaction of the Ukrainian public administration included two stages concerning educational institutions. At the first stage, starting on March 12, all educational institutions were quarantined [19]. The administration and teachers of educational institutions were ordered to prepare for the transition to e-learning. At the second stage, the quarantine was extended from March 26 to April 24 [20]. Since March
26 , all $100 \%$ of classes were in the e-learning form.

Once again, Ukrainian universities switched to the distance learning due to COVID-19 since October 12, 2020. This decision was made following the meeting with the President of Ukraine, Volodymyr Zelenskyy [21].

In Ukraine, on January 8, 2021, the lockdown, strict quarantine restrictions, began to operate [22]. The universities cannot be visited - students must take the session remotely.

Thus, responding to the threat of COVID-19, the Ukrainian public administrations increased the share of e-learning to $100 \%$. Such public decisions were made to take care of student health.

At the same time, no one knows what the student needs for e-learning in Ukraine are. And no one knows whether these public decisions meet student needs. Therefore, it is of practical and scientific importance to explore Ukrainian student needs in e-learning.

\subsection{Primary Processing and Grouping of the Experiment Results}

The Ukrainian student needs in e-learning are shown in Table 2. These survey data were obtained from 2018 till 2019 , as in the paper [12]. Thus, these data were obtained just before the outbreak of the COVID-19.

Table 2. Ukrainian student needs in e-learning just before the outbreak of the COVID-19

\begin{tabular}{|c|c|c|c|c|c|}
\hline No & Specialty & $\begin{array}{c}\text { Number, } \\
\mathrm{N}\end{array}$ & $\dot{\mathrm{X}}$ & $\delta_{\mathrm{x}}$ & $\delta_{\mathrm{x}-1}$ \\
\hline \multicolumn{6}{|c|}{ Ukraine } \\
\hline 1 & $\begin{array}{c}\text { Law, 1st degree, } \\
2-4 \text { years }\end{array}$ & 25 & 54,20 & 21,33 & 21,77 \\
\hline 2 & $\begin{array}{c}\text { Law, 2nd degree, } \\
1-2 \text { years } \\
\end{array}$ & 15 & 68,66 & 21,86 & 22,63 \\
\hline 3 & $\begin{array}{l}\text { Electromechanics, } \\
\text { 1st degree, } 3 \text { years }\end{array}$ & 15 & 52,50 & 24,19 & 25,27 \\
\hline 4 & $\begin{array}{l}\text { Medical business, } \\
1 \text { st degree, } 5 \text { years }\end{array}$ & 27 & 20,92 & 23,13 & 23,57 \\
\hline 5 & $\begin{array}{l}\text { Pharmacy, 1st } \\
\text { degree, } 2 \text { years }\end{array}$ & 30 & 24,66 & 26,98 & 27,94 \\
\hline 6 & $\begin{array}{c}\text { International } \\
\text { economic } \\
\text { relations, 1st } \\
\text { degree, } 4 \text { years }\end{array}$ & 15 & 38,57 & 12,45 & 13,45 \\
\hline 7 & $\begin{array}{l}\text { International } \\
\text { economic } \\
\text { relations, } 2 \text { nd } \\
\text { degree, 1 year }\end{array}$ & 15 & 38,47 & 33,99 & 35,27 \\
\hline
\end{tabular}

Table 2 shows the expected value (X) for Ukrainian student needs in e-learning. Table 2 does not give a clear idea of any correlations.

The verification of statistical hypotheses allows getting new scientific knowledge about student needs in e-learning in Ukraine.

The new sample for the statistical comparison of public decisions and the Ukrainian student needs in e-learning (Table 3) was drawn up. In Table 3, the expected value (X) 
for each of the respondent groups was used to calculate the new statistical indicators. The expected values $(\dot{\mathrm{X}})$ were taken from Table 2.

Table 3. Summary table of Ukrainian student needs in e-learning

\begin{tabular}{|c|c|c|c|c|c|}
\hline \multirow{2}{*}{ No } & \multirow{2}{*}{ Country } & \multicolumn{4}{|c|}{ Statistical indicators } \\
\cline { 3 - 6 } & & $\begin{array}{c}\text { Number of } \\
\text { Respondent groups, } \mathrm{n}\end{array}$ & $\dot{\mathrm{X}}$ & $\delta_{\mathrm{x}}$ & $\delta_{\mathrm{x}-1}$ \\
\hline 1 & Ukraine & 7 & 0,43 & 0,16 & 0,17 \\
\hline
\end{tabular}

Table 3 shows that student needs in e-learning in Ukraine are $\dot{X}=0,43(\dot{X}=43,00 \%)$. This value is less than the share of e-learning $(100,00 \%)$ recommended by public decisions of the Ukrainian authorities.

The statistical indicators of Table 3 allow verifying the statistical hypotheses $[12,16-18]$ about the relationship between the public decisions on student health care during the COVID-19 pandemic era in Ukraine and student needs in e-learning. Thus, this allows us to find out the answer to the question of whether the public decisions on student health care during the COVID-19 pandemic era meet student needs in e-learning.

\subsection{The Verification of Statistical Hypotheses whether Public Decisions on Student Health Care during the COVID-19 Pandemic Era in Ukraine Meet Student Needs in E-Learning}

As it is shown in part 4.1., COVID-19 has forced Ukrainian public administration to increase the share of e-learning to $100 \%$. It means that public decisions on student health care during the COVID-19 pandemic era meet Ukrainian student needs when student needs in e-learning are equal to $100 \%$.

In this case, the authors accept the value 1,0 (one) for the forced level of e-learning at the universities. The research hypothesis [16-18] is written in the form: $\mu_{0}=$ 1,0 .

The research hypothesis is student needs in e-learning are equal to $100,0 \%$ [16-18] if random deviations will not be taken into account.

The alternative hypothesis is written: $\mu_{0} \neq 1,0$.

The alternative hypothesis is student needs in e-learning are not equal to $100 \%$ [16-18] if random deviations will not be taken into account.

The method of hypothesis testing about the average general population is to calculate t-statistics [18]. Table 4 shows the results of the verification of statistical hypotheses.

If in Table 4, t-statistics in absolute $\left|t_{\text {stat }}\right|$ is larger than the $t_{\text {tabl }}$, we reject the research hypothesis and accept the alternative hypothesis [16-18]: student needs in e-learning are not equal to $100 \%$ if random deviations will not be taken into account.

The observed difference between the statistical average $\dot{X}$ and the specified value of $\mu_{0}=1,0$ can not be explained by randomness only [16-18]. Since the difference exceeds simple randomness, Ukrainian student needs in e-learning are not equal to $100 \%$ [16-18] if random deviations will not be taken into account.

Table 4. Verification of statistical hypotheses: Ukrainian student needs in e-learning are equal to $100 \%$. The checking level is $1,0 \%$

\begin{tabular}{|c|c|c|}
\hline No & Indicator & Result \\
\hline 1 & Sample size, $\mathrm{n}$ & 7 \\
\hline 2 & Average of sample, $\dot{\mathrm{X}}$ & 0,43 \\
\hline 3 & Standard deviation for sample, $\boldsymbol{\delta}_{\mathbf{x}}$ & 0,16 \\
\hline 4 & Average error, $\dot{\mathrm{S}}_{\dot{\mathrm{X}}}=\boldsymbol{\delta}_{\mathbf{x}} / \sqrt{\mathrm{n}}$ & 0,062 \\
\hline 5 & Value $\left|\mathrm{t}_{\text {stat }}\right|$ for $\mu_{0}=1,0,\left(\dot{\mathrm{X}}-\mu_{0}\right) / \dot{\mathrm{S}}_{\dot{\mathrm{X}}}$ & 9,194 \\
\hline 6 & Value $\mathrm{t}_{\text {tabl }}$ for significance level $99,0 \%$, & 3,707 \\
\hline 7 & {$[16, \mathrm{p} .42]$} & Yes \\
\hline 8 & Result, $\left|\mathrm{t}_{\text {stat }}\right|>\mathrm{t}_{\text {tabl }}$ & Alternative \\
\hline
\end{tabular}

It was statistically proved that public decisions on student health care during the COVID-19 pandemic era don't meet student needs in e-learning. The key hypothesis was not accepted [16-18]. The result is highly statistically significant $(0,01)$.

Thus, the goal of this empirical study was achieved. The authors found out the answer to the question of whether public decisions on student health care during the COVID-19 pandemic era in Ukraine meet student needs. This answer is "no, public decisions on student health care during the COVID-19 pandemic era in Ukraine do not meet student needs".

So, the difference between public decisions and student needs in e-learning should be taken into account when taking public decisions on student health care during the COVID-19 pandemic era.

\section{Discussion}

What do the results show?

First, the COVID-19 pandemic has forced the Ukrainian public administration to increase the share of e-learning to $100 \%\left(\mu_{0}=1,0\right)$. Such public decisions [19-22] were made to take care of student health.

Second, student needs in e-learning can be described as following: $\dot{X}=0,43(\dot{X}=43 \%) ; \delta_{x}=0,16 ; \delta_{x-1}=0.17$.

And finally, public decisions on student health care during the COVID-19 pandemic era [19-22] don't meet student needs in e-learning.

How can we consider the results?

This empirical study shows that Ukrainian universities must educate students through $100 \%$ e-learning [19-22]. This value $(100 \%)$ is more than the student needs $(43 \%)$. This means that the forced decisions of the Ukrainian public administrations violate the student rights as educational services buyers [11-14, 23-26]. Students, as educational services buyers [11-14, 23-26], have the right to acquire everything they see fit. And these public 
decisions violate students' academic freedoms. In particular, it is the freedom to choose teaching methods [27].

The use of e-learning at the universities is not only inevitable, but it also offers new educational opportunities [28]. Ukrainian professors must use effective and interesting methods of e-learning. Shalva Amonashvili [29] has written "The technical capabilities of distance learning must be impeccable, perfect, so that just click a button and the teacher appears, sees the student - and communication begins as if they are standing next to each other. Today, technologies are not ready for educational processes, for higher education..." [29]. Therefore, the university authorities should equip universities for e-learning very well.

In the practical part, the significance of the results means that Ukrainian public administrations and the university authorities should communicate with students and resolve this situation after the COVID-19 pandemic will be overcome. Also, the legal framework, such as [19-22], must be changed according to the current situation, academic freedoms and student rights as educational services buyers [11-14, 23-26].

In the theoretical part, the theory of learning should be adjusted taking into account the share of e-learning equal to $100 \%$.

Are 142 respondents enough to get a reliable result in this empirical study?

For example, as many as 60 students become the sample in the study [9]. The next study [10] was conducted by a survey on a study sample of 104 elite athletes respondents in Jakarta. In the article [30], it was 84 respondents only. The research [31] was carried out with the participation of 15 university students only.

So, the authors see that 142 respondents are enough to get a reliable result in this empirical study. Thus, in this study, the independent opinions of 142 respondents were transformed into new scientific knowledge.

The results were accepted for the standard significance level of $99,0 \%$. It shows that the solutions will be correct in approximately $99,0 \%$ of cases and incorrect only in $1,0 \%$ of cases. We have a decision-making process with accurate, controlled probability [16-18].

\section{Conclusions}

The purpose of this empirical study has been achieved the authors get the answer to the question of whether public decisions on student health care during the COVID-19 pandemic era in Ukraine meet student needs.

The key hypothesis has been checked.

This empirical study gives us six new knowledge:

1. The analysis of public decisions on student health care during the COVID-19 pandemic era in Ukraine shows that the COVID-19 pandemic has forced Ukrainian public administrations to increase the share of e-learning to $100 \%$.
2. The analysis of student needs in e-learning in Ukraine shows that student needs in e-learning in Ukraine are equal to $43 \%$. This value ( $43 \%$ ) seems to be less than the share of e-learning recommended by public decisions of the Ukrainian authorities (100\%).

3. The comparison of public decisions on student health care during the COVID-19 pandemic era and student needs in e-learning shows that the difference is statistically significant.

The alternative hypothesis was accepted: student needs in e-learning are not equal to $100 \%$ if random deviations will not be taken into account.

This result is obtained through the verification of statistical hypotheses. The result is highly statistically significant $(0,01)$. So, we have a decision-making process with accurate, controlled probability.

This scientific knowledge links the COVID-19 epidemic and public decisions to the violations of the student rights as consumers of educational services and students' academic freedoms.

4. The importance of the results in the practical part means:

- Ukrainian professors, managers and educators must use effective and interesting methods of e-learning.

- University authorities should equip universities for e-learning very well.

- Ukrainian public administrations and university authorities should communicate with students and resolve this situation after the COVID-19 pandemic will be overcome.

- The higher education legal framework must be changed according to the current situation, academic freedoms and student rights as educational services buyers.

5. In the scientific part, the theory of learning should be adjusted taking into account the share of e-learning equals $100 \%$. This empirical research can help fill a sector in world scientific literature on the researched subject and contribute to the identification of new areas for analysis and development of learning theories.

6. The results of this empirical study demonstrate the necessity to research further issues related to the topic. It is certainly worth repeating the empirical analyses on a much larger and more diverse sample, which would enable the results to be extrapolated into the entire population of Ukrainian students. It can be useful for learning theory to study deeply gender differences between respondents, which would enable new study results to be published. At the same time, we need to study how the sudden transition to $100 \%$ of e-learning affected mental and physical student health. They are the tasks for the next study. 


\section{Acknowledgements}

The study was conducted with the assistance of the East European Scientific Group. The authors thank the respondents for their time spent studying the questionnaire and answering the questions.

Each of authors thanks reviewers for their useful comments on the earlier draft of the article.

\section{Appendix 1}

\section{Characteristics of the Ukrainian respondents}

\begin{tabular}{|c|c|c|c|c|}
\hline № & Specialty & Number, $\mathrm{n}$ & Forms of study & University \\
\hline \multicolumn{5}{|c|}{ 1. Humanities } \\
\hline 1 & Law, 1st degree, $2-4$ years & 25 & full-time & $\begin{array}{l}\text { V. Dahl East Ukrainian } \\
\text { National University }\end{array}$ \\
\hline 2 & Law, 2nd degree, 1-2 years & 15 & full-time & $\begin{array}{l}\text { V. Dahl East Ukrainian } \\
\text { National University }\end{array}$ \\
\hline \multicolumn{5}{|c|}{ 2. Technical Sciences } \\
\hline 3 & Electromechanics, 1st degree, 3 years & 15 & full-time & $\begin{array}{c}\text { Kharkiv National University } \\
\text { of Urban Economy }\end{array}$ \\
\hline \multicolumn{5}{|c|}{ 3. Natural Sciences } \\
\hline 4 & Medical business, 1 st degree, 5 years & 27 & full-time & $\begin{array}{c}\text { Vinnytsia National Medical } \\
\text { University } \\
\end{array}$ \\
\hline 5 & Pharmacy, 1 st degree, 2 years & 30 & full-time & Rivne Medical Academy \\
\hline 6 & $\begin{array}{l}\text { International economic relations, 1st degree, } 4 \\
\text { years }\end{array}$ & 15 & full-time & Dnipro National University \\
\hline \multirow[t]{2}{*}{7} & $\begin{array}{l}\text { International economic relations, 2nd degree, } 1 \\
\text { year }\end{array}$ & 15 & full-time & Dnipro National University \\
\hline & Total respondents: & 142 & - & - \\
\hline
\end{tabular}

\section{REFERENCES}

[1] Q. Li, et al. Early transmission dynamics in Wuhan, China, of novel coronavirus-infected pneumonia, New England Journal of Medicine, 382(13), 1199-1207, 2020.

[2] WHO (11 March), Director-General's opening remarks at the media briefing on COVID-19, 2020. Retrieved from https://www.who.int/dg/speeches/detail/who-director-genera 1-s-opening-remarks-at-the-media-briefing-on-covid-19---11 -march-2020

[3] L. Xing, et al. Anxiety and depression in frontline health care workers during the outbreak of Covid-19, International Journal of Social Psychiatry, October 2020 doi:10.1177/0020764020968119

[4] F. Liang, COVID-19 and Health Code: How Digital Platforms Tackle the Pandemic in China, Social Media + Society, 6:3, July 2020. doi:10.1177/2056305120947657

[5] N. Kalyanaraman, M.R. Fraser, Containing COVID-19 Through Contact Tracing: A Local Health Agency Approach, Public Health Reports, 136(1): 32-38, 2021. doi: $10.1177 / 0033354920967910$

[6] A. Roy, et al. Mental health implications of COVID-19 pandemic and its response in India, International Journal of Social Psychiatry, September 2020. doi:10.1177/002076402 0950769

[7] O.E. Nabofa, et al. Mental Wellbeing and Exercise Participation during COVID-19 Pandemic among Adult Residents of Nigeria's Niger Delta, International Journal of Human Movement and Sports Sciences, 8(6): 534-542, 2020. DOI: $10.13189 /$ saj.2020.080628

[8] A.M. Stelnicki, R.N. Carleton, C. Reichert, Nurses' Mental Health and Well-Being: COVID-19 Impacts, Canadian Journal of Nursing Research, 52(3):237-239, 2020. doi: $10.1177 / 0844562120931623$

[9] J. Hasanuddin, et al. Online Learning and Platforms Favored in Physical Education Class during COVID-19 Era: Exploring Student' Perceptions, International Journal of Human Movement and Sports Sciences, 9(1): 11-18, 2021. DOI: 10.13189 /saj.2021.090102

[10] K. Aisya, A. Khurotul, D.M. Elly, Jakarta Athletics Training during the COVID-19, International Journal of Human Movement and Sports Sciences, 8(6A): 57-62, 2020. DOI: 10.13189/saj.2020.080710

[11] L. Bunce, A. Baird, S. E. Jones. The student-as-consumer approach in higher education and its effects on academic performance, Studies in Higher Education, 42:11, 1958-1978, 2017.

[12] V. Okulich-Kazarin, M. Zhurba, I. Shorobura, et al. 
Comparison of Educational Preferences of Polish and Ukrainian Students at Lectures, Universal Journal of Educational Research, 8(8), 3666 - 3672, 2020.

[13] V. Okulich-Kazarin, M. Zhurba, I. Shorobura, et al. Three characteristic features of the East European educational services market, Universal Journal of Educational Research, 8(4), 1549-1556, 2020.

[14] V. Okulich-Kazarin, Four Levels of Organization of Educational Activity of Educational Service Providers, Universal Journal of Educational Research, 8(10): 4870-4876, 2020. DOI: 10.13189/ujer.2020.081059

[15] A.I. Kravchenko, Sociologia: textbook for students [in Russian], M.: Yurayt, 2014.

[16] Textbook for the Program "Masters of Business Administration". BUS 9641_Business_Statistics_3, USA, NY, Kingston University, $200 \overline{9}$.

[17] Textbook for the Program "Masters of Business Administration". BUS 9641 5M. Business_Statistics. USA, NY, Kingston University, 2010.

[18] V. Minashkin, Teoria statistiki [in Russian], Textbook. M.: EAOI, 2008.

[19] Рішення Уряду, Загальнонаціональний карантин продовжено до 24 квітня - рішення Уряду, 2020. Retrieved from https://mon.gov.ua/ua/news/zagalnonacional nij-karantin-prodovzheno-do-24-kvitnya-rishennya-uryadu

[20] Два сценарії розвитку подій. Trivatime navchalnij rik dati zno ta yak vidbuvatimetsya vstup, 2020. Retrieved from https://mon.gov.ua/ua/news/dva-scenariyi-rozvitku-podij-ski lki-trivatime-navchalnij-rik-dati-zno-ta-yak-vidbuvatimetsy a-vstup

[21] Ukrainian universities switch to distance learning due to COVID-19. Retrieved from https://sputnik.by/education/202 01011/1045879025/Vuzy-Ukrainy-perekhodyat-na-distantsi onnoe-obuchenie-iz-za-COVID-19.html

[22] Tightening of quarantine from January 8: what will change.
Retrieved from https://coronavirus.rbc.ua/rus/news/uzhestoc henie-karantina-8-nvarya-izmenitsya-1609347783.html

[23]A. Network, Rights of consumers. Retrieved from http://www.dl5.ru/400-prava-potrebitelej.html

[24] S. I. Belentsov, A.V. Fahrutdinova, G.Y. Grevtseva, et al. Free education: Fundamentals of humanistic pedagogics (on the example of activity of the German public figures of the second half of XIX - the beginning of the XX centuries of F. Gansberg, L. Gurlitt, G. Sharrelman). European Journal of Contemporary Education, 8(1): 201-207, 2019.

[25] V. Okulich-Kazarin, What Method of Learning do Media Students Prefer at Lectures: Auditory or Visual? Universal Journal of Educational Research, 8(6), 2660 - 2667, 2020.

[26] W. Okulicz-Kozaryn, Comparison of distance learning offers by Polish and Ukrainian Universities before COVID-19, International Journal of Humanities and Natural Sciences, 4-3(43), 28-36, 2020.

[27] V. Shram, Realization of academic freedoms of students in the education system. Bulletin of Adyghe State University. Series 3: Pedagogy and Psychology, 4. 122-123, (2007).

[28] W. Kwiatkowska, The Identity of Young Adults and their E-learning Performance. e-mentor, 3(80), 18-23, 2019. DOI: $10.15219 / \mathrm{em} 80.1419$

[29] S. Amonashvili, We must change. New children do not fit in the old pedagogy. Chalk, 2020. Retrieved from https://mel.fm/istorii/3254791-shalva_amonashvili

[30] S. Chukwuedo, T. Ogbuanya, Potential pathways for proficiency training in computer maintenance technology among prospective electronic technology education graduates, Education + Training, 62(2), 100-115, 2020. https://doi.org/10.1108/ET-07-2019-0146

[31] Fil. Kayalar, Fet. Kayalar, The effects of Auditory Learning Strategy on Learning Skills of Language Learners (Students' Views). IOSR Journal Of Humanities And Social Science (IOSR-JHSS), Volume 22, Issue 10, Ver. VII, 04-10, 2017. 